\title{
Alien Invasions and Identity Crisis: Steven Spielberg's The War of the Worlds (2005)
}

\author{
Rocío Carrasco Carrasco \\ Universidad de Huelva \\ rocio.carrasco@dfing.uhu.es
}

\begin{abstract}
The idea of national identity as threatened by foreign invasions has been at the centre of many popular Science Fiction (SF) films in the United States of America. In alien invasion films, aggressive colonisers stand for collective anxieties and can be read "as metaphors for a range of perceived threats to humanity, or particular groups, ranging from 1950s communism to the AIDS virus and contemporary 'illegal aliens' of human origin" (King and Krzywinska, 2000: 31-2). Such films can effectively tell historical and cultural specificities, including gender concerns. In them, the characters' sense of belonging to a nation is destabilised in a number of ways, resulting in identity crisis in most cases. A fervent need to defend the nation from the malevolent strangers is combined with an alienation of the self in the search of individual salvation or survival.

The present analysis will attempt to illustrate how threats to configurations of power are employed in a contemporary alien invasion film: The War of the Worlds (Steven Spielberg, 2005). Specifically, the film takes the narrative of destruction to suggest the destabilisation of US national power within the context of post September 11, together with a subtle disruption of the gender and sexual status quo. Indeed, new ways of understanding masculinity and fatherhood assault both the public and the private spaces of its white male heterosexual protagonist, Ray, performed by popular actor Tom Cruise. Ambiguous patriotism, identity crises and selfishness are at the core of this contemporary version of H.G. Wells's landmark novel.
\end{abstract}

Keywords: science fiction, masculinity, identity crisis, 9/11, patriotism 


\section{Introduction: the alien as a threat in the SF movie}

The figure of the alien in its multiple guises is often depicted in SF films as an intruder or as an evil creature, violating the boundaries existing between the self and the 'other'. There is a general tendency to show a terrifying, different and marginalised 'otherness' as opposed to familiar, healthy and reassuring depictions of the dominant 'one'. The latter is normally linked to the human being, and specifically to the white male hero. In relation to this issue, Vivian Sobchack classifies popular SF images into three categories -the alien, the familiar, and an intermediate category that fuses them. The tension among these three categories is what is specific to SF films (Sobchack, 1987: 87). Indeed, and as it will be argued below, the mere presence of the alien itself destabilises biased configurations of power, causing identity crisis on most SF protagonists. The antagonism between the 'one' and the 'other' can be analysed adopting different lines of thought, since the category 'other' offers many ideological, political and/or psychoanalytic interpretations. In general terms, it has been argued that the 'other' suggests social and cultural fears.

Political, cultural, family and gender issues are raised in films that picture aggressive alien invasions, where an unfamiliar presence threatens to challenge current configurations of power. Indeed, the hero's antagonistic relationship with the 'other' conditions plot structure. In particular, this topic was especially relevant in SF and horror films of the 1950s. Popular films of this decade, like The War of the Worlds (Haskin, 1953) or The Thing from Another World (Nyby, 1952) portray this challenge of power structures through the topic of the foreign alien attack. Suggesting the Cold War ideology of 'containment', these films reproduce the typical anxieties of the times. The extraterrestrial monster of The Thing and the Martian tripods destroying the Earth in The War of the Worlds seem to evoke latent collective fears. As in most alien invasion movies, both heroes are confused and disoriented and must struggle not only against the invading alien but also against the inefficacy of their governments when attempting to solve a problem that affects national security. The male need of facing a superior enemy in the form of a massive alien invasion is present in many other SF films of the 1950s. Although a less remarkable example, Earth versus the Flying Saucers (Sears, 1956) also shows the need to fight a devastating and powerful enemy, this time in the form of UFOS landing all over the Earth. Male aggression is also necessary, together with technology, to fight the alien threat. Cornea argues in this sense that "the male scientist certainly picks up the mantel of power, but only once he has demonstrated that he can fight like a man and assure the survival of the world" (49). The need of a 'superior male force' seems to be the solution for the survival of the nation.

The Cold War paranoia of a communist invasion is evoked in what we may denominate 'body invasion' films. Invasion of the Body Snatchers (Siegel, 1956), Invaders From Mars (Sears, 1953), It came from Outer Space (Arnold, 1953) or I Married a Monster from Outer Space (Fowler, 1958) depict alien beings who invade and/or penetrate human bodies, causing identity problems. This process of possession depicted in the films threatens to destabilise familiar distinctions between the 'one' and 
the 'other', human and alien (King and Krzywinska, 2000: 51). In them, there are no physical fights or battles against the aliens but an invasive appropriation of the body that affects both the space of the family and the relationship of the heterosexual couple. Invasion of the Body Snatchers invokes a neurotic world that confronts 'us' (the United States of America) versus 'them' (alien invaders), and where the hero -Doctor Miles Fennel- is alarmed. Apart from the common reading as a representation of the anxieties of communist infiltration and atomic conflict, Invasion of the Body Snatchers can be analysed as a disruption of 'healthy' male patriarchy. Katrina Mann analyses the film in this light and contends that it makes use of xenophobic tropes of racial and sexual difference to dramatize the social, political and personal disruption of US hegemonic white patriarchy (Mann, 2004: 49). She might be referring to the film's suggestion that this alien enemy that infiltrates US society and turns individuals into hostile and emotionless beings disturbs the status quo of the 'American way of life'. The alien menace is depicted as a force that invades human bodies and turns individuals into hostile, emotionless and asexual pod people. The body becomes, then, a site of suspicion, since anybody can be one of 'them'. Hence, infested male bodies fail to spot the connotation of social power. It is precisely this alien takeover what produces an identity crisis in the male protagonist. Fostered by the 50 s social climate of paranoia, the 'other' represents disease and contamination, since it spreads like an infection among the population. The monstrous 'other' penetrates its victims while they are sleeping, causing them to surrender their identity. Aliens that literally transgress the limits of the human body threaten the 'healthy' values of US society.

Fear of women's authority and reproductive roles are also present in films that follow the topic of the aggressive alien extraterrestrial. In "Gender in NineteenthCentury Science Fiction: The Female Alien and the Woman Ruler", Robin Roberts argues that it is the female alien's ability to reproduce that makes her so threatening to the male protagonist and to patriarchal society (1993: 20). Accordingly, by encountering the female alien, the male hero recognises and defines his own masculinity and that of the dominant culture. If we follow this argument, the film Attack of the 50 Foot Woman (Juran, 1958) can be considered as an instance of how female sexuality graphically threatens humanity in SF of the 1950s.

Specifically, the image of the alien as a 'foreigner' is at the centre of many ideological readings. In colonial discourse, the 'other' is normally constructed as that which is unfamiliar to the dominant ideology of the West. In this sense, Loomba argues, the limits between civilisation and barbarism lie on the production of a conflicting difference between 'black' and 'white' (57). ${ }^{1}$ The construction of the 'other' as a dangerous outsider prevails in many SF films, where the alien invader is associated to images of barbarism, aggression and difference. This difference needs to be eliminated since it threatens to enter and disrupt Western society. In relation to this issue, Adam Roberts argues that SF "comes out of the Age of Empires because it is a necessary part of the official ideology of Empire-forming that difference needs to be flattened, or even eradicated" (Roberts, 2000: 65). SF serves, then, the dominant ideology of the twentieth-century American Empire. 
The menace of non-Western values is further suggested in many SF films released after the 1950s. The topic of the extraterrestrial invader that threatens US institutions specially privileges this reading. For instance, in Independence Day (Emmerich, 1997) the source of threat is the extraterrestrial 'other', which is considered as evil and dangerous. The film implies that the eradication of outsiders is necessary for the whole world to survive and for US supremacy to remain intact. In this sense, and taking into account the 1990s Golf-War crisis over US political and social integrity, and the general unease towards illegal immigration, the radical 'other' might be associated with the negative concept of blackness, despite the fact that Will Smith plays a starring heroic role. In relation to the film's 'dark' aliens, Mair argues: "During the Middle Ages, Islam was the darker Other of Europe (...) During the Cold-War, communism acquired the mantle of alien Other. The post-Cold War West returns to Islam" (Mair, 2002: 37). The film hints a plea for 'Americaness', significantly constructed as plural in the film, as evidenced by the heterogeneous and racially mixed group of people who is to save the world. For that, the eradication of alien 'outsiders' seems to be necessary.

In addition, and especially in some contemporary alien invasion films, gender and racial issues are questioned and revisited by means of humour and direct allusion to how SF has traditionally presented the 'other' as a threat to normative structures of power. For instance, the film Mars Attacks! (Burton, 1996) makes use of traditional 'fears' and revisits them through parody. From the beginning of the film, the Martians' flying saucers invading the Earth are not meant to be threatening for humankind, that is seen dependent on TV and mass-media. Indeed, the Martians are believed to be peaceful and the president of the U.S.A, James Dale (Nicholson), prepares a warm welcome for them twice. Against any predictions, the small Martians attack and kill the civil population, unveiling their evil purposes. Popular SF movies like The War of the Worlds, Earth vs. the Flying Saucers, Godzilla or Alien are parodied in the movie. Neither president James Dale nor the famous professor Donald Kessler (Brosnan) initially show any apprehension but, on the contrary, believe in the Martians' peaceful nature. They are so confident about their own scientific and political superiority that they see no real reason to worry about the Martians' threat. However, the aliens humiliate and betray them, what can be analysed as human incapacity to deal with and understand the condition of the 'other'. Cultural misunderstandings, fostered by a context of uncertainty and paranoia towards an alien attack, echo the US panorama at the turn of the millennium.

In short, the encounter with difference is effectively reflected in many SF films. Sexual and racial differences disrupt the 'American norm' and are normally depicted as threats in the form of invading aliens or monsters.

\section{The national border, patriotism and self-survival in The War of the Worlds}

The War of the Worlds (2005) was directed by Steven Spielberg and written by Josh Friedman and David Koepp. It is a version of H.G. Wells's 1898 novel with the same 
title, which was adapted for the radio in 1938 by Orson Welles and taken to the big screen in 1953 by Byron Haskin and producer George Pal. Apart from Haskin's and Spielberg's adaptations, Jeff Wayne's 1978 musical version of The War of the Worlds inspired later musicals and computer game versions.

Like other alien invasion films, both versions of The War of the Worlds are centred on the opposition between self/other. The films place their main male characters at the privileged side of the binary opposition and the extraterrestrial beings that invade the Earth at the deviant side. Hence, the 'other' is depicted as fearful and repulsive. The films' invasion narrative reflects different threats that destabilise people's confidence at each historical moment. While Haskin portrays the 1950s generalized context of the Cold War paranoia, Spielberg re-imagines Wells's scenario to provide us with a metaphor of the terrorist threat in the U.S.A. after September 11. In addition, the familiar trope of the confrontation 'us' versus 'them' serves as a vehicle to include instances of identity crises, which surfaces in different ways in these two films.

Haskin's The War of the Worlds (1953) mirrors the socio-political issues that were under threat during the 1950s implying that the 'others' are pernicious beings with colonial aspirations and, therefore, should be exterminated. The decline of US world power and the Cold War ideology of containment against 'intruders' are implied in the film. Scientist Dr Clayton Forrester (Barry) feels disoriented because of the meteors that are invading the world. His first reaction, shared by most of the population, is to hide and to warn others about the forthcoming danger. Humanity reacts in a negative way against the appearance of these alien presences, with the exception of a couple of men who try to approach the visitors and, as a result, are immediately killed. Consequently, the whole community is scared and the first reaction is to be distant and sceptic. This behaviour can be interpreted as a product of their disorientation and anxiety towards the 'foreigner' and society's inability to deal with the appearance and acceptance of disturbing 'others'. This is reinforced by reiterative sentences like 'it is the oddest thing I've ever seen' and by the Martians' association to an annoying sound. Like many other films of the $1950 \mathrm{~s}$, the alien is represented as a malignant force, intent on destroying human civilisation.

As a way to overcome this political crisis one needs to fight against the enemy and, for that purpose, the military forces are called. The army is a sign of authority and power at times when a decline of US world power is evident. It also evokes the destructive technologies used in previous world wars while showing contemporary advances in arms manufacturing. The political context of terror and the fear of a communist invasion are unmistakably materialised in the film.

Likewise, Spielberg's The War of the Worlds (2005) portrays both the anxiety of mass hysteria and the individual confrontation with contemporary fears. The film becomes an allegory of the trauma and panic felt in the United States of America as a consequence of the devastating attacks of the World Trade Center in Manhattan and the Pentagon in Washington DC on 11 September 2001. The film makes use of images of devastation and scenes of massive destruction, suggesting an apocalyptic scenario that resembles disaster films. As Cornea argues, disaster films encourage a comparison with 
the earlier world war period. Indeed, the "[p]aranoia and political undercurrent might be seen to return in the serious remakes of recent years, as set against the political protectionism marked by so-called 'war on terror' and the threat from a somewhat nebulous al-Qaeda" (2007: 33). Disaster films proliferate especially in times of crisis and have renewed their popularity after the terrorist attacks of 2001. The popularity of these images of destruction is, according to Jean Baudrillard, a result of everyone's fantasy of seeing the destruction of any hegemonic power. Hence, the attraction these disaster films exert "shows that acting-out is never very far away, the impulse to reject any system growing all the stronger as it approaches perfection or omnipotence" (Baudrillard, 2002: 7). Accordingly, our dreaming of this event justifies, then, the spectacle of mass destruction on the World Trade Center. What becomes clear, as it is contended here, is that The War of the Worlds takes advantage of this popularity of images of destruction to pose questions on the problematics of the breaking of a national identity, together with the questioning of male authority.

The alien attack triggers a rupture of the national border. The geopolitical concept of nation is a Western idea that emerged under specific economic circumstances. It has become one of the most important modes of social and political organisation in the modern world (McLeod, 2002: 68) and has been defined as 'imagined political community' by postcolonial criticism (Anderson, 1991: 6). The War of the Worlds breaks with the so-called 'myth of the nation', which, in McLeod words, has the following defining features:

- Nations are imagined communities.

- Nations gather together many individuals who come to imagine their simultaneity with others. This unified collective is the nation's 'people'.

- Nations depend upon the invention and performance of histories, traditions and symbols which sustain the people's specific identity continuous between the past and the present.

- Nations evoke feelings of belonging, home and community for the people.

- Nations stimulate the people's sense that they are the rightful owners of a specific land.

- Nations standardise a unitary language accessible to all people.

- Nations are often narrated through forms of representation which promote the unities of time and space.

- Nations place borders that separate the people 'within' from different peoples outside. (McLeod, 74-5)

The feeling of defending the 'nation' has proved to be a powerful symbol to many anti-colonial movements against the colonial rule. ${ }^{2}$ Accordingly, to construct a national consciousness is essential for the struggle for independence. ${ }^{3}$ Although the 'myth of the nation' might function as a valuable tool for the pursuit of liberty and progress, it also encompasses a conflict which Partha Chatterjee calls 'liberal dilemma' (Chatterjee, 1993: 4). For the achieving of this ideal community, undemocratic forms of government are sometimes employed. Moreover, nationalism is normally associated to aggression, 
violence, domination and irrationality and, as such, it has proved to be a problematic term.

In The War of the Worlds, borders are threatened. Yet, the feeling of connectedness to pursue 'liberty' from the colonising alien tripods does not work. Instead, people are seen in fight for individual survival, what does not fit into the 'national myth' described by McLeod. The attack is taken by surprise and the population does not really know what is happening, especially at the very beginning of the movie. When the first lightning appears, Ray does not seem to be frightened since he believes it to be something 'cool', even funny, a mere product of the season. Little by little people start to worry about 'weird' lightning, including his daughter Rachel, who confesses her fears and pleads for fatherly protection. Thus, no real struggle against the enemies is at first appreciated in the movie, apart from one taken up by the army and police forces. The construction of a national consciousness seems to be at a very early stage.

Self-reliance combined with mutual assistance, which has been remarked as a fundamental American virtue, is absent from the movie. Regarding the effects of the rising equality of social conditions on the individual in the context of early $19^{\text {th }}$ century America, the French political thinker and historian Alexis de Tocqueville wrote in 1835:

Americans (...) are fond of explaining almost all the actions of their lives by the principle of interest rightly understood; they show with complacency how an enlightened regard for themselves constantly prompts them to assist each other, and inclines them willingly to sacrifice a portion of their time and property to the welfare of the state. (647)

Yet, in the film individuals are mainly concerned with their own interest and selfsurvival. There is no unified collective or sense of belonging to any imagined community. Apart from showing the evil nature of the 'other', Spielberg's film demonstrates the insanity that can infect us all at moments of tremendous crisis (Vest, 2006: 70). Indeed, the most frightening moments in the movie involve not the conflict between aliens and humans, but those depicting humans fighting for survival, which account for a situation of mass insanity. This corresponds, on the other hand, to Wells's belief in the destructive nature of civilisation per se (Aoun, 2006: 233).

The film stresses selfishness. As a consequence of the invasion, cars do not work, except that of Ray's friend, which he manages to get without consent. Leaving his friend behind, Ray drives away with his two kids. From this moment onwards, this car becomes the target of many people who would use any means to get it, since it entails a hope for survival. Humans are mainly concerned with individual salvation, what increases paranoia and confusion. Aggression, chaos and hysteria are especially recreated in the sequences of the ferry when everybody tries to cross the Hudson River. Rachel screaming and people running and fighting for survival reinforce the chaos. The use of weapons helps to reassert power and to establish who the strongest is and, therefore, who is to cross the river to a supposed salvation. Darwin's theory of the survival of the fittest seems to be a rather 'relative' concept here. At these tough moments, Ray is seen crying and feeling desperate. He manages, however, to get his 
two kids on the ferry with him. However, this kind of 'heroic' deed is soon to be undermined by Ray's inability to help a friend and her daughter, whom he meets just before embarking the ferry. He is not able to take care of friends either. As this sequence evidences, the film portrays an unorganised and selfish society, victim of the attacks of a devastating enemy, and unable to collectively fight against it.

Patriotism, or the proud feeling of belonging to a nation, can suggest an effective way to contribute to fight against a common enemy. ${ }^{4}$ However, as it has been illustrated, this collective responsibility is denied in favour of self-interest in The War of the Worlds. In relation to this issue, Vest affirms that the film "is a vibrant, terrifying, and observant examination of how American democracy, generosity, and liberty are the most precarious of ideas and institutions when under assault by alien aggressors" (2006: 68). Vest believes in the film's critique of the patriotic fervour that has recently characterized the United States and sees the film's political implication in different sequences. At a key moment, the son's protagonist, Robbie, spurns fatherly authority and protection. Vest studies the political subtext in this sequence, arguing that these different generational attitudes towards military service in times of war resonate with contemporary discussions of the appropriateness of recruiting high school students for service in Iraq and Afghanistan (69). Apart from echoing recent debates about military policies, I believe that the sequence denounces the false or dubious patriotism that has characterised the United States of America after the terrorist attacks in 2001.

Robbie's decision to fight for the nation is interpreted here as a product of his disorientation and family problems. Previously in the movie, Robbie's relationship with his father has been depicted as troublesome and distant. Robbie admits wanting to see the war with his own eyes. He needs to feel better with himself and he sees an opportunity to do so by enlisting in the army. That way, he will not depend on his father's decisions and will be able to show determination and courage. Also, he will stand out from a mass of people only interested in self-survival. Robbie's supposedly patriotic feeling is partly grounded on individual interests as much as on the lack of a stable father figure. Hence, the problematic father-love is displaced to the service of the nation. As Homi K. Bhabha contends in "Are you a Man or a Mouse?" the anxiety about the domestic scenario of problematic father-love can be displaced into another kind of anxious love-amor patriae - which is the naturalistic, phallic identification with the service to the nation. The instinct for respect -central to the civic responsibility for the national service- comes from the father's severity, which is an effect of his 'peripheral' position in the family. In this sense, the father is a kind of 'phallic peripherality'. It is the absence of the father that constitutes the principle of national self-identification and the service of a nation. This gendering of the nation's domestic metaphor makes its masculinism neurotic (103-4). If we take into account this argument, Robbie's decision to join the army can be read as a projection of his anxious love to the nation.

Another instance of an ambiguous 'patriotism' comes from the mentally disturbed character of Ogilvy (Williams), who openly claims he would die for the country. In the basement, Ogilvy confesses that he has a plan to fight the tripods and in doing so, 
liberate his country from this threat. This sequence in the basement accounts for the different reactions towards the coming of the 'other', suggested by Ray and Ogilvy's attitudes towards the aliens. Indeed, and as Ogilvy himself confesses, they 'are not on the same page'. Ogilvy has a plan to create a resistance movement against the aliens and Ray prefers to continue unnoticed and hidden, in an attempt to save his daughter from harm. Ogilvy is firm to stop the 'occupation', as he himself denominates the alien plan. He states that they are going to be the ones coming from the underground this time.

After they witness an alien capturing a human being and draining all his blood, they both panic. Ogilvy turns mad and starts shouting 'Not my blood' and digging a tunnel in frenzy, while Ray's behaviour is far from heroic. Afraid that Ogilvy's screams may attract the aliens, Ray decides to kill him. In Wells's novel, the narrator kills the curate accidentally when trying to calm him. This act is intentionally done in Spielberg's film and, far from being a heroic deed, demonstrates the character's hysterical reactions produced by the presence of the 'other'. Ray and Ogilvy's irrational behaviour show a lack of understanding and organisation when struggling against the 'other'.

The military forces stand, then, as the only instance of a joint struggle against the enemy. As the film develops, however, it becomes evident that the military forces cannot deal with the enemy in an effective way. The superiority of the tripods is latent, especially in sequences where we see them in comparison with masses of people who shiver with terror when encountering them. Still, at chaotic moments, some sort of authority seems to be needed, embodied here, as happened in Haskin's film, by police forces and the army. With this, the film denounces the idea that force and violence are effective ways to reduce the anxieties of a nation. According to Brian M. Jenkins, the best way to increase the nation's ability to respond to disasters is "to enlist all citizens through education and engagement, which also happens to be a very good way to reduce the persistent anxieties that afflicts [the United States]" (2006: 156). In reference to the terrorist attacks on September 11 and the policies adopted after them, Jenkins claims that the United States of America has not responded to them in an effective way. He claims for public education, information and the need for a reasonable 'patriotism' to strengthen US society after the devastating attacks. In a similar way, the film uses the topic of the hostile alien invasion to suggest this uncertainty and lack of agreement and engagement to face the problem of an aggressive invasion.

\section{Terrorism and identity crisis}

Kim Newman affirms that Wells's novel is difficult to adapt "in that it is like a compilation of personal experiences and second-hand news items, with a nameless narrator whose only plot function is to be there" (Newman, 2005: 83). Spielberg's film is complicated with family problems, which also echo the dynamics of Wells's book Following this line of thought, Vest affirms that "[t]he end of the world evokes a morbid fascination for Spielberg's audience no less than for Wells's readers, rehearsing some of American's most fundamental cultural anxieties to suggest that our lot in life is 
to endure civic insecurity, political ambivalence, and fractured family relationships" (Vest, 2006: 71). Faithful to its sources, Spielberg manages to mirror contemporary anxieties, evoking symbolic commentaries about the concerns present in the United States of America at the beginning of the $21^{\text {st }}$ century, which include questions of gender identity.

Steven Aoun affirms in Metro 149 (2006) that while Wells used the book as a vehicle to teach Western civilization the lesson of 'natural selection' Spielberg's War of the Worlds, nonetheless, "manages to be more adaptable by looking East and West simultaneously" (233). Specifically,

Spielberg's movie is a colonial object that may be directed towards culturally specific anxieties (...) Given the cinematic language, Spielberg's film can speak to (and reassure) conflicting worldviews regarding the rise of terrorism or spread of imperialism. (233)

Accordingly, the movie gives expression to both left and right wings critiques in relation to terrorist and imperialist matters. Aoun is of the opinion that producers decided to include both approaches in order for the film to become a success in an international context. The resulting product is, I believe, an expression of the times' uncertainty, and political and cultural specific worries.

Released in a context of urban terror, the film reflects the view of everyday US citizens towards the dangers of terrorism and the crisis caused by it. Significantly enough, the alien tripods erupt from beneath the Earth surface and are controlled by alien creatures that aim at a massive destruction of the world. Once the cells emerge from the underground, a general mood of chaos and destruction permeates the film, reinforced by the reiterative use of close-ups of Ray's terrified face. As opposed to the 1953 film, the church is the first building to be destroyed by the menacing 'other'. While in Haskin's version the church served as an element of union, salvation, and romantic encounter, in Spielberg's the first alien cell emerges precisely from it. Religious beliefs do not seem to have a place, then, in the globalised world that the disturbing 'other' plans to get hold of by means of aggression. The impious destruction of this symbol adds tension to the narrative. With it, Spielberg shows the contemporary situation of the Western man, who has lost credibility as a father and as a world international policeman. Religion is not a refuge any more. Men are to do by themselves and cannot get comfort in religion or in the traditional nuclear family.

We get sequences which strikingly resemble the events that took place on 11 September 2001. Vest sees this and argues that "[t]he parallel to the images of New York City residents covered in the dusty ash of the collapsed Twin Towers on 9/11 is unmistakable, and Ray reacts with the same horror that we saw etched across too many faces on that fateful day" (68). Ray arrives home covered in dust and ashes and, in a clear Lacanian allusion, looks himself in the mirror, getting a terrible image of a frightened and desolated Ray who realizes about his fears. His defensive strategy is to take his gun, a rather ridiculous act if we take into account the overwhelming supremacy of the tripods. Yet Ray needs to 'feel' male power. From this moment onwards Ray heads for the stability and equilibrium suggested by his ex-wife. 
George W. Bush spoke of the War on Terror, which entailed an effort on the part of the United States of America to combat terrorism and finish with radical organisations like Al Qaeda. Al Qaeda's war aims are basically political, and it is widely believed among US citizens that this terrorist group has an arsenal of weapons of mass destruction. The question "Are we safer now?" has become frequently asked in the United States of America (Jenkins, 2006: 145). The War of the Worlds makes allusions to this social terror. Rachel is constantly asking her father about their safety and about the origin of the attacks. Significantly, the children's first reaction towards the coming of the tripods is to think of a terrorist attack, what implies their familiarisation with these matters. This is especially seen in a sequence that shows the moment after Ray discovered about the existence of the tripods and is driving towards his ex-wife's house with the children. After Ray has taken his two kids to their mother's house, he decides to hide in the house's basement for protection. In the midst of his disorientation and insecurity, Ray resorts to his gun. His insecurity is suggested in a scene in complete darkness after another alien attack, and only Rachel's whisper is heard: "Are we still alive?" Sequences like this tell human's powerlessness in the face of the massive attacks, what resonates with religiously based terrorism.

Moreover, events like 9/11 provoked trauma and shattered the sense of national identity. Even those who did not lose friends or loved ones or were not in New York that day experienced secondary or vicarious trauma via the media (Gordon, 2007: 254). Trauma revises, then, a whole vision of patriarchal culture. In relation to this topic, Cathy Caruth proposes that there is a deep disconnect between what is experienced and what is assimilated and, therefore, the trauma "is not experienced as a mere repression or defence but as a temporal delay that carries the individual beyond the shock of the first moment" (7-10). A process of discovery best understands experiences of trauma. Literature, films and sociology, among others, are ways of thinking about and responding to the experience of trauma. Caruth is of the contention that in a catastrophic age trauma can provide the link between cultures not only because we can recognize the past of others but also because it enables us to listen through the departures we have all taken from ourselves (11). In our encounter with trauma we can, then, rethink our notions of experience and get a new understanding of history.

After September 11 the paranoia of a possible terrorist attack in the United States of America has caused the use of controversial strategies and campaigns against terrorism. One of the largest obstacles to dealing with threats from terrorism came from the 9/11 Commission, whose final report of July 2004 remarked a 'failure of imagination'. According to such report, the United States of America needed to anticipate and prepare for what terrorists might do next:

Sending waves of suicide bombers to America's shopping malls, demolishing Boston's waterfront with a sabotaged liquefied-natural-gas (LNG) carrier, bringing down the George Washington Bridge in New York City, crashing a plane into the White House or a nuclear reactor, spraying a major urban center with anthrax, sinking tankers to block narrow straits, unleashing hoof-and-mouth disease, bringing down the banking system, spreading 
smallpox, vaporizing Manhattan with a nuclear bomb, all once considered far-fetched, became presumptions. (Jenkins, 149)

The belief in these presumptions has led to a panorama of paranoia and mass hysteria, as reflected in Spielberg's film and in other cultural products. Moreover, the advance of globalisation, which encourages the lack of borders, and technological developments like the Internet or mobile phones contribute to facilitate terrorist communication. Danger can be anywhere and potential terrorist attacks help to keep the country on edge. Mass media and the public domain of the existence of these threats further help to construct and extend social terror. Organisations like Al Qaeda had openly manifested to be hostile to western civilization: "its cosmopolitanism, secularism, materialism, sensuality, arrogance, support of women's rights, and obsession with technology" (Patterson, 2005: 380). Jenkins rightly points out an added problem when taking action against terrorism in general. Terrorists are normally denounced "as mindless fanatics, savage barbarians, or, more recently, 'evil-doers'words that dismiss any intellectual content" (53). The United States has defined terrorism according to the quality of the act, not the identity of the terrorists or the nature of their cause (54). This angry rhetoric and the desire to see the terrorist as evil impede any effort to understand the enemy and to consequently formulate effective responses to terrorism.

All these factors create a sense of frenzy, which is reflected in the film. Camera movement helps create this generalised feeling of disorientation and uneasiness. Subjective shots and a fast moving camera provide realism to the scenes. Hoberman affirms in Sight and Sound (2006) that the film went into production immediately after Bush's election and "like the president, Spielberg sought to invoke the trauma that precipitated America's current war and, not coincidentally, scare the bejeezus out of the U.S. public" (22). Spielberg talked about 'an ultra-realistic' film with clear references to terrorism and war that ultimately resolves the horrible events it represents:

Its narrative trajectory is informed by a particular political logic. In tracking the emotional development of the frightened child's father (Tom Cruise) from callow, immature hotshot to responsible mensch, War of the Worlds provides an allegory of George W. Bush's crisis -inspired growth into leadership- or at least of the audience's willingness to grant him that growth. (Hoberman, 23)

Yet, Ray is somehow obliged to develop his 'responsible' side as a consequence of the desperate situation he is living. Whether the film finally resolves the events it echoes or not, the extended presence of trauma and the depiction of a population in crisis suggest the dismantling of traditional power structures.

Indeed, the male protagonist is a metaphor of the contemporary man in crisis. Although not all men were unemployed or unhappy, studies have revealed how at the end of the $20^{\text {th }}$ century, masculinity was troubled and "American men remain bewildered by the sea of changes in our culture, besieged by the forces of reform, and bereft by the emotional impoverishment of our lives" (Kimmel, 1996: 330). 
Specifically, The War of the Worlds engages with the uncertainty produced by a shifting concept of family and how identities are inevitably affected by these changes.

Ray is at odds with his role as a father. The coming of the extraterrestrials has given Ray new parental duties and, out of necessity, he has to take up childcare. He is overwhelmed by his new responsibility. His children become alien to him, which recalls the dissolution of the nuclear family. He does not conform, then, to the middle class, sensitive "New Father" models proposed by critics like Pleck and Pleck in "Fatherhood Ideals in the United States" (1997). Ray does not behave either as the modern Hollywood father, sometimes weak but usually morally upstanding, like the one embodied by Michael Douglas in Fatal Attraction and Traffic (Bruzzi, 153). Instead, Ray's behaviour escapes conventional heroic patterns.

In "Child/ Alien/ Father: Patriarchal Crisis and Generic Exchange", Vivian Sobchack deals with the cultural meanings of the child and how this figure has contributed to a generic convergence between contemporary SF, horror and family melodrama. Indeed, many films have been 'marked' as contemporary not only because of their release dates but also by "their mutual figuration of the alien or Other as somehow implicated in family life" (4). Sobchack argues that American bourgeois family has experimented a crisis since the $60 \mathrm{~s}$ and this is shown in films like The Terminator, E.T. or Close Encounters. The family and its members are seen as subjected to dissolution, transformation and redefinition: “A man's home in bourgeois patriarchal culture is no longer his castle (...) It is no longer possible to avoid the presence of Others -whether poltergeists, extra-terrestrials, or one's own alien kids" (Sobchack, 1991: 4). The figure of the child condenses a cultural drama that seeks resolution in the three genres. Whereas SF manages to offer a promise to resolve the conflict, there are no such resolutions available to either the horror film or the family melodrama -both playing out patriarchal impotence. Accordingly, otherness can be found both outside and inside the family. In this sense, The War of the Worlds shows a menaced man who is unable to cope with this situation. An absent father, a feature that became common in the Lucas-Spielberg's blockbuster movies of the $80 \mathrm{~s}$, sees traditional family relationships as disturbed.

As a matter of fact, the family is not excluded from socio-political concerns and conflicts in US society but it becomes a mirror of them. In relation to the reading of family dynamics, Sobchack observes that rather than serving bourgeois patriarchy as a place of refuge from the social upheavals of the last two decades, it has become their site and serves as a sign of their representation (1991: 5). Ray's fractured family cannot stand as a place of escape from the problems of the outside world, but it becomes an allegory of them. Bemused and unable to find any alternative, Ray starts a journey towards stability still at hand by the promise to be a responsible father.

Ray is depicted as a menaced and fragile man who needs to defend himself against the 'other'. One of the ways to inscribe discourses of superiority on screen is by displaying a muscled body, which is, nevertheless, neutralised here by the presence of the huge tripods that make Ray appear as weak and ineffectual. In other words, the gigantic alien machines highlight Ray's physical vulnerability. Yet, there are some 
sequences in which the notion of invisibility is tempting. The sequence at the ambulance driver's basement echoes the one in the 1953 film that presented the hero and heroine on a deserted farm. At its climax, Ray, Rachel and Ogilvy are hiding first from the sneaky alien searching for any human trace and then from the three aliens that enter the basement. This section is characterised by an agonic silence and an economy of movement (70), which turns out to be quite symbolic for the purposes of this analysis. Ogilvy's first reaction is to take an axe and try to chop the alien's long neck in two, to what Ray persuades him -using body language- not to do so. ${ }^{5}$ Yet, he tries again and Ray is forced to kill him. The need of invisibility for survival is urged, then, in this sequence. Hence, apart from this social concept of invisibility, the film's plot also suggests the need of becoming invisible in order to survive. Ray -and humankind in general- needs to hide from the enemies if they want to live.

Once the aliens have disappeared, there is a feeling of hope for the re-establishment of the status quo. At the end of the film, not coincidentally set in puritanical Boston, the family is reunited and we learn about the stability suggested by tradition. The movie's reliance on previous texts also contributes to the emphasis on the reproduction of certain gender types. In addition, the presence of some actors and actresses in Haskin's 1953 version -Gene Barry and Ann Robinson- as the protagonist's ex-parents-in-law at the end of Spielberg's film also fosters the continuity of tradition, which is an instance of Spielberg's debt to his predecessor.

One can argue, therefore, that the film acts out the debates around the man in crisis. The political context of paranoia and fear of the foreigner, together with the inability to face family life, affect US society in general, male hegemony and the representation of the hero in Hollywood cinema in particular. The coming of the evil aliens evokes different fears and anxieties present in the United States of America at the time of the film's premiere (2005). Whereas the 'other' is read as an allegory of Islamic terrorism, or as hints of current changes concerning masculine roles, or as mere allusions to pollution and disease, it has always been taken as marginal. Indeed, Ray is in crisis precisely because of the presence of this foreign 'other'. Ray is frustrated as a consequence of his fear, anxieties and notorious inability to deal with the 'other'.

\section{Conclusion}

As commented here, in The War of the Worlds (Spielberg, 2005), the alien invasion topic has political overtones and contributes to recreate a state of mass hysteria. The movie suggests culturally specific anxieties, such as the dissolution of national borders, terrorism and gender trouble.

Ray evokes contemporary worries concerning the depiction of masculinity in the context of SF. The notion of the 'other' is constructed within the traditional negative parameters associated to what remains outside the norm. Ray's controversial relationship with the 'other' has contributed to stress notions of anxiety and insecurity. In order not to be exposed as soft -one of the worst things a man can 'suffer' in our 
culture (Bordo, 55)- Ray feels an identity crisis since he is unable to prove his strong manly core.

At another level, Ray's relationship with his familiar world is, likewise, far from trouble-free. Indeed, he has got a difficult relationship with his family and does not know how to play the father's role in the chaotic world surrounding him. Contrary to what happened in Haskin's film, in Spielberg's the male character cannot find peace and comfort in the private realm of his family and is detached from the pleasures provided by a romantic liaison. Traditional family values, religious beliefs and romantic union are absent from Ray's life. He cannot face the reality surrounding him and behaves frantically in the face of difficulties. Ray's failure to finish with the aggressive enemy is reinforced by his inability to deal with his new familiar situation, which prevents him from fitting into the conventional heroic type. Far from being a site of comfort and safety, his family becomes a source of agitation. Otherness is also present within his familiar context.

Due to the general feeling of panic and anxiety in his private and public life, Ray cannot evolve into traditional heroic patterns. Rather, he is an ambivalent figure which perfectly epitomises a man in crisis.

\section{Notes}

1. In his influential Orientalism (1978), Edward Said interrogates colonial power and argues that representations of the Orient in European literary texts were based on the binary opposition European self and non-European 'other'. This fact contributed to maintain European hegemony and power over the 'other'.

2. As Timothy Brennan contends in "The National Longing for Form", the "myth of the nation' is ambiguous since it does refer, not to the idea that nations are mythical, but to the way that various governments invent traditions to give permanence and solidity to a transient political form (Brennan, 1990: 47).

3. Fanon is of the belief that writers and intellectuals should be responsible for resisting colonialism in their works. The construction of a specific national consciousness should be accompanied by the creation of a distinctly national culture, which, according to Fanon, moves through three phases. In the first phase, the writer or artist attempts to 'assimilate' the dominant trends. In the second, he/she is dissatisfied with copying the colonizer and turns backwards to the history of the people. The third phase is the fighting phase in which he/she becomes involved in the struggle against the colonial rule (Fanon, 1967: 179-82).

4. In 'Notes on Nationalism' (1945) George Orwell makes a distinction between a virtuous 'patriotism' and an aggressive 'nationalism'. Nationalism is a feeling of superiority about one's way of life, country or ethnic group whereas patriotism is a feeling of admiration for one's way of life and the willingness to defend it against any attack. The post-war context for Orwell's article results meaningful for his theories about nationalism.

5. This sequence recalls the Alien films, where the monstrous "other" hides in the spaceship and humans become anxious by the possibility to come across it. 


\section{References}

Anderson, Benedict (1991): Imagined Communities: Reflections on the Origin and Spread of Nationalism. London: Verso.

Aoun, Steven (2006): "Reel to Real: War of the Worlds". Metro, 149: 233-234.

Baudrillard, Jean (2002): The Spirit of Terrorism and Requiem for the Twin Towers. Trans. Chris Turner. London: Verso.

Bhabha, Homi. K., ed. (1990): Nation and Narration. London: Routledge.

Bhabha, Homi. (2000). “Are You a Man or a Mouse?” In Ann Tripp, ed., Gender. New York: Palgrave, 102-108.

Bordo, Susan (1999): The Male Body. A New Look at Men in Public and in Private. New York: Farrar, Straus and Giroux.

Brennan, Timothy (1990): “The National Longing for Form”. In Bhabha (1990), 44-70.

Bruzzi, Stella (2005): Bringing Up Daddy. Fatherhood and Masculinity in Post-War Hollywood. London: BFI.

Caruth, Cathy, ed. (1995): Trauma: Explorations in Memory. Baltimore: The Johns Hopkins University Press.

Chatterjee, Partha (1993): Nationalist Thought and the Colonial World. A Derivative Discourse. London: Zed Books.

Cornea, Christine (2007): Science Fiction Cinema. Between Fantasy and Reality. Edinburgh: Edinburgh University Press.

Fanon, Frantz (1967): The Wretched of the Earth, trans. Constance Farrington, 1961. London: Macgibbon and Knee.

Gordon, Andrew (2007): Empire of Dreams. The Science Fiction and Fantasy Films of Steven Spielberg. Lanham, MD: Rowman \& Littlefield.

Hoberman, J. (2006): "Hollywood and U.S. TV: Unquiet Americans". Sight and Sound, 10: 2023.

Jenkins, Brian. Michael (2006): Unconquerable Nation: Knowing Our Enemy. Strengthening Ourselves. Santa Monica: The Rand Corporation.

Kimmel, Michael. S. (1996): Manhood in America. A Cultural History. New York: The Free Press.

King, Geoff. and Tanya. Krzywinska (2000): Science Fiction Cinema. From Outerspace to Cyberspace. London: Wallflower.

Loomba, Ania (1998): Colonialism-Postcolonialism. London: Routledge.

Mair, Jan (2002): “Rewriting the 'American Dream': Postmodernism and Otherness in Independence Day." In Ziauddin Sardar and Sean Cubitt, eds., Alien $R$ Us. The Other in Science Fiction Cinema. London: Pluto Press, 34-50.

Mann, Katrina (2004): "You're Next! Postwar Hegemony Besieged in Invasion of the Body Snatchers". Cinema Journal, 44(1): 49-68.

McLeod, John (2000): Beginning Postcolonialism. Manchester: Manchester University Press.

Newman, Kim (2005): "War of the Worlds". Sight and Sound, 15: 83-84.

Orwell, George (1945). "Notes on Nationalism". http://www.orwell.ru/library/essays/ nationalism/english/e nat.

Patterson, James T. (2005): Restless Giant: The United States from Watergate to Bush vs Gore. Cary, NC: Oxford University Press.

Pleck, Elizabeth. H. and Joseph. H. Pleck, eds. (1980): The American Man. Englewood Cliffs: New Jersey. 
Roberts, Adam (2000): Science Fiction. London: Routledge.

Roberts, Robin (1993): A New Species. Gender and Science in Science Fiction. Urbana and Chicago: University of Illinois Press.

Said, Edward W. (1978): Orientalism. London: Routledge.

Sobchack, Vivian (1987): Screening Space: The American Science Fiction Film. 1980. New York: Ungar.

Sobchack, Vivian (1991): "Child/Alien/Father: Patriarchal Crisis and Generic Exchange". In Constance Penley et al., eds. Close Encounters: Film, Feminism and Science Fiction. Minneapolis: University of Minnesota Press, 3-32.

Tocqueville, Alexis de (2000) [1835]: Democracy in America. Chicago: University of Chicago Press.

Vest, Jason (2006): "Film Reviews: Future's End: Steven Spielberg's War of the Worlds (2005)". Film and History, 36: 67-70. 